In: Hungarian educational research journal

(HERJ), 2013. (3. évf.), 4. sz., 64-77

\title{
PÉTER TÖRÖK
}

\section{What Should We Pay Attention To? Some Preliminary Information on the Value System of the Students in the Network of Church-Run Roma Special Colleges}

\begin{abstract}
The study presents both a brief description of the Hungarian network of Roma special colleges run by the so-called historical churches of the country as well as an outline of the research conducted among the students. The results reported in this study can be considered only preliminary, because the network of these colleges has started only recently, consequently, the number of students whose value system has so far been surveyed through an adapted version of EVS questionnaire is rather small. The preliminary results indicate that the Roma students participating in the network are definitely religious but do not participate regularly and frequently in religious services. Furthermore, they trust the churches and the educational system.
\end{abstract}

Keywords: Roma/Gypsy values, students in higher Education, European Value Studies, religion, education.

\section{Introduction}

The so-called Hungarian historical churches, i.e. the Catholic, Reformed and the Lutheran churches established the Network of Church-run Roma Special Colleges (NoCRoSC) in 2011. Apart from conducting research among the Roma/Gypsy ${ }^{1}$ students of these colleges, researchers and educators of the Institute of Mental Health (Semmelweis University, Budapest, Hungary) offered help to the students in coping with the complexity of higher education as well as cultural differences. The current study first presents briefly the history and the structure of NoCRoSC which is followed by a short description of the complex, tripartite research conducted among the Roma/Gypsy students. The third part will report some preliminary results of the value survey conducted among the students. Due to the preliminary nature of the results, instead of a thorough discussion I conclude the study with one of the

\footnotetext{
${ }^{1}$ The term Romani is used by several political organisations - including the United Nations, the Council of Europe, and the US Library of Congress referring to the ethnic group who trace their origin to the Indian Subcontinent. They are widely dispersed throughout Europe, with their largest concentrated populations in Spain and Romania. Recently, they have also immigrated to the Americas (USA and Brazil) and, to a lesser extent, to North Africa and the Middle East. For self-designation, the term Roma is also common in Central and Eastern Europe. The Romani people are also known by a variety of other names, in English as Gypsies and Roma. While the term Gypsy is considered by some in Hungary as degrading, others point out proudly that they are not Roma, but Gypsies. Consequently I will use both terms in the present study.
} 
noteworthy differences between the Hungarians and the Roma/Gypsy students of these colleges.

\section{The History and Structure of NoCRoSC}

Reflecting on the socially, economically, and culturally dreadful situation of the Roma/Gypsy people in Hungary ${ }^{2}$, the three traditional Christian churches and their various organisations ${ }^{3}$ decided to work out what they called the Christian alternative for Roma integration. ${ }^{4}$ As a result, on $17^{\text {th }}$ March, 2011, the Network of Church-run Roma Special Colleges was established. The network loosely connects the institutions that took upon the task to provide boarding for the Roma/Gypsy youth who successfully passed the entrance examination and were accepted in the system of Hungarian higher education.

Although the Network of Church-run Roma Special Colleges has a rotating directorate, and regular meetings are held to exchange information and share good practices, the independency and autonomy of the participating institutions are safeguarded. The colleges arrange their inner life separately; and decide their organisational structure without any external influence. The only requirement is that three modules must be present in their curricula. These modules are the HungarianRomani integration-builder module, the spiritual module, and the preparation for public role module.

The colleges provide the students with different services in accordance with the three basic modules. Regarding educational support, for example, they provide tutoring by university professors and preparation for language exams. The intention of NoCRoSC is the integration of the Roma/Gypsy students into the Hungarian society. While it necessarily means the improvement of their Hungarian identity, the colleges also want to strengthen the students' Roma identity. What is more, they want the students to develop and firmly establish a positive Roma identity. For this purpose, Romani culture is taught extensively. Not surprisingly, among the aims of the founders a solid Christian worldview can also be found. They also expect the students to prepare for an active public role, initiating public dialogue and taking up public responsibilities. The final goal, however, is to orient the graduated students back to their original community, therefore, they are encouraged to and helped to maintain connections with their family and original community.

\footnotetext{
2 See, for instance, Kemény, Janky and Lengyel (2004), Kertesi (2005), and Kállai and Törzsök (2006).

3 Within the Catholic Church, the Jesuit Order and Greek Catholics participate in this programme.

${ }^{4}$ In April 2011, the Hungarian government, as holder of the presidency of the European Union, launched a highly acclaimed Roma strategy.
} 
Apart from the three-module curricula, there is one more common feature in these colleges. According to the regulations of the network, colleges might accept non-Roma/Gypsy students, i.e. Hungarians as well, in order to facilitate common living, but the proportion of these students cannot exceed 25 percent. With the exception of one college where there are only Roma/Gypsy students, all the others accept non-Roma/Gypsy students as well (Forray \& Marton, 2012).

\section{The Tripartite Research}

Researchers of the Institute of Mental Health (IMH) had their first contact with the Roma/Gypsy students in 2011 when the students first entered the Semmelweis University, the country's oldest - and until recently an exclusively - medical school with high prestige. The disadvantaged Roma/Gypsy students had to cope not only with the stress originating from the highly expected intensive study but occasionally with conflicts stemming from prejudice and cultural differences. The employees of IMH decided to offer the students help in the forms of psychodramatic conflict resolution and personal counselling if needed. They also saw the opportunity of conducting research among the Roma/Gypsy students at Semmelweis University; and prepared an elaborate, tripartite research consisting of a life-story review and surveying both the value system and the network of the Roma/Gypsy medical students who received boarding in the first Roma special College launched by the Jesuit Order in Budapest in 2011. The research was authorised both by Semmelweis University and the Jesuit Order.

However, due to the extensive media attention to the Roma/Gypsy students both at the university and in the Jesuits' college, other institutions and even private individuals intended to carry out research projects. They started to overwhelm the Roma special college with requesting permission for their research and even bothered the individual students to fill out questionnaires and give interviews. In an attempt of avoiding further conflicts, the leaders of the Roma special college in Budapest asked IMH to be a strategic partner of NoCRoSC in the capacity of research coordinator in the whole network. It also meant the expansion of the original tripartite research covering all of the students in the five church-run Roma special colleges.

As a pilot study, the research was conducted among the students of the college in Budapest in the academic year of 2011-12. It became evident that probably as a consequence of the frenzied media attention and researchers' interest the students were very sensitive to any expressed consideration of their life. They manifested unrealistic fears - such as the possibility of identification in case the 
third world war breaks out - when asked to participate in the research, therefore, we had to emphasise from time to time the anonymity and voluntary participation. ${ }^{5}$

For the life-story reviews students were asked to narrate their life focusing on questions such as how they achieved or arrived in their current position, who helped them, what their identity was, etc. ${ }^{6}$ Referring to the possibility that they would be examples, ideals, and role models for other Roma/Gypsy children and young people, ${ }^{7}$ they were also asked what they think of that. On average, the life-interviews lasted about three hours.

The examination of the students' personal network was carried out through the so-called contact diary method (Huszti, Dávid \& Vajda, 2013). Students were asked to keep a registry for a week, recording each evening in the entries the names of the persons - with pseudonyms - their gender, and the relationship between them. A contact should not exhaust itself in greeting somebody, but required at least a five minute discussion either in person or in other communication ways, such as telephone, Skype, internet, etc.

This paper will focus on the values of the Romani students of these colleges, therefore, the research method employed in this area is discussed in a more detailed way. While the direction of changes in the identity of Romani intelligentsia in Hungary is well-documented (Kende, 2005; Lukács, 2011; Szabóné, 2005; Tóth, 2004), researchers know very little about the general values, let alone value changes of the Romani intelligentsia. Perhaps the only exception is Kyuchukov's study (2011), in which he examined how and to what extent traditional values - such as preserving a girl's virginity - influenced Roma/Gypsy girls' educational chances in Bulgaria.

From a sociological point of view, as indicated in the above example of Roma/Gypsy girls' traditionally valued virginity, the values of individuals and social units are very important. If certain values are accepted and legitimised in a given society or its subgroups, these values determine and create the base of the norms, and consequently, the behavioural patterns of the members of that society or subgroup (Morel, 1989). The European Value Studies are probably the most

\footnotetext{
${ }^{5}$ C.f. the data in Table 1.

${ }^{6}$ For similar interviews, see Forray (2004a) and Pusztai (2004). The latter notes that religious communities have not only integrative effect but they also help educational mobility.

${ }^{7}$ Students of the special Roma college in Miskolc, run by the Greek Catholic Church, were taken to the elementary school of a nearby village with a dominantly Roma/Gypsy population. The schoolchildren were informed only about the visit of university students, but the students' Roma/Gypsy identity remained hidden. When they entered the classroom, the Roma/Gypsy children could not help expressing their astonishment, which even intensified when the students told them that they would become lawyers, information specialists, etc.
} 
elaborated and complex surveys conducted in a longitudinal form to analyse the basic values of the European continent. So far four waves have probed the European societies, including Hungary in 1981, 1990, 1999 and 2008.

For the measurement of the students' value system, an adapted version of the European Value Studies questionnaire was used. ${ }^{8}$ While the proceedings of the survey employ interviewers, the adapted version is self-administered, which was made possible by the instructions of the modified questionnaire. Students are asked to fill in the questionnaire on their own, but if they still have questions they can turn to the researchers on the spot. The adapted version, which was used to probe the value system of the students in the special Roma colleges, was first essentially the same as the questionnaire of the EVS. However, it soon became clear that there are several items in the EVS questionnaire which are either not applicable to or not conceivable for the students. In the second year of our research, therefore, a comprised version of the survey is employed, omitting the items considered unnecessary. Nevertheless, apart from demographic data even this shortened version of the questionnaire covers such topics as views on democracy, work, marriage, family, religion, trust in others and in particular institutions, child-raising issues, social responsibilities, identity, regionalism, moral questions, etc.

The scientific investigations on the students' value system and their network are according to the researchers' plans longitudinal; expecting the students to report their network each year while their value system is probed when they enter the college and when they graduate.

\section{Preliminary Results of the Value Survey}

The employment of the EVS survey will make it possible in the long run to compare our results with Hungarian and European data. However, the results reported in this study can be considered only preliminary, because the network of these colleges has started only recently, consequently, the number of students whose value system has so far been surveyed is rather small (Table 1). ${ }^{9}$ It is small even if the number of processed questionnaires includes the questionnaires filled in by the Budapest students of the previous (2011) year when we did the pilot study of the project, and consequently, the total number of questionnaires is 78 . Thus, the presentation of our data serves simply the purpose of sharing information. It is hoped, however, that these data can highlight some possible trends to which we should pay attention in

\footnotetext{
${ }^{8}$ From the numerous publications reporting general, continent-wide results of the EVS, see, for example, Ashford \& Halman (1994), Halman, Sieben and Zundert (2011), or for the study on Hungarian values, see Rosta and Tomka (2010), or Török, Martos and Horváth-Szabó (2010).

${ }^{9}$ The number of the filled in questionnaires also indicates the voluntary nature, and - perhaps more strikingly - how suspicious the students were even with our research.
} 
the future when more data is available and thus more sophisticated statistical analysis is possible. ${ }^{10}$

Table 1. The number of students and the number of filled in value-system questionnaires in the church-run special Roma colleges in 2012

\begin{tabular}{lcccccc}
\hline Location & Budapest & Nyíregyháza & Szeged & Debrecen & Miskolc & Total \\
Student \# & 29 & 20 & 15 & 22 & 17 & 103 \\
Questionnaire \# & 12 & 14 & 8 & 5 & 17 & 46 \\
\hline
\end{tabular}

In line with the focus of this volume on education and religion, this paper will provide some data on the students' general priorities, belief system, and religious customs, views on what children should be taught, and trust in different institutions, etc.

\section{General priorities}

The Roma/Gypsy students in the church-run special colleges value the same items in the same rank-order as the Hungarian population (Table 2). By and large, not only the rank-order of the items is the same, but the mean values of the items are rather similar. Only the importance of religion is significantly higher among NoCRoSC students than that of the Hungarians, which is not surprising if we consider that these students are in church-run institutions. Although the differences are statistically not significant, it is noteworthy that for the Roma/Gypsy students, in contrast with their stereotypically strong commitment towards close relatives, especially children, family is less important and work is more important than for the Hungarians. The consistency of these trends must be checked in future analysis when more data is available.

\footnotetext{
${ }^{10}$ A further consideration must be mentioned here. While admitting that the presentation of results in the tables in percentages might be statistically less appropriate when the total number of questionnaires did not reach 100, the use of percentages was the only way to create an analysable and - especially in the long run - comparable data format.
} 
Table 2. Priority rank-order of the NoCRoSC students and the Hungarian population (the lower the value, the more important the item is).

\begin{tabular}{lll}
\hline How important is in your life? & & \\
Rank order & NoCRoSC & Hungarians \\
1. Family & 1.18 & 1.10 \\
2. Work & 1.47 & 1.59 \\
3. Friends, relatives & 1.53 & 1.70 \\
4. Free time & 1,82 & 1.77 \\
5. Religion & $2.16^{*}$ & 2.66 \\
6. Politics & 2.95 & 3.05 \\
\hline
\end{tabular}

* Significance level: 0.001 .

Data source for Hungarian population: EVS 2008

\section{Belief System and Religious practices}

Nine out of ten students belong to a denomination. The missing ten percent might be surprising if we talk about Christian colleges, but the churches, apparently do not request religious belonging when they select the students. However, the selfreported atheism of a student surprised even the religious leader supervising the college. $^{11}$ Almost all of them, more than four-fifth of the students consider themselves religious which is definitely higher than the national average (56.4 percent). ${ }^{12}$ Regarding the content of their belief system, in comparison with the Hungarian averages as Table 3 indicates, the students of these colleges are definitely much more religious than their peers. (All the differences are significant at the level of 0.001.) The data also indicates that the meaning system of their beliefs is rather inconsistent, or at least, it is not in accordance with the basic tenets of Christianity. For belief in reincarnation or the power of amulets is definitely against what Christians should believe in.

\footnotetext{
${ }^{11}$ When we process the data of each college, we provide a feedback to the students where the leaders of the college can also be present. The anonymity of results is also meticulously preserved during these feedbacks.

${ }^{12}$ Here I have to rely on the EVS survey instead of the national census of 2011. In the census it was not obligatory to answer the questions probing religious belonging and ethnic identity. Thus 27.2 percent of the Hungarian population did not answer the questions inquiring about religiosity. Furthermore, many question the reliability of the census, because even during the surveying period many problems surfaced. The problems did not seem to stop with the actual surveying time, the procession and the publication of the data took more than a year (!).
} 
Table 3. Some elements of the belief system of NoCRoSC students and the Hungarian population

\begin{tabular}{lll}
\hline $\begin{array}{l}\text { Believes in ... } \\
\text { Content }\end{array}$ & NoCRoSC (\%) & Hungarians (\%) \\
God & $96^{* * *}$ & 73 \\
Life after death & $77^{* * 8}$ & 35 \\
Hell & $65^{* * *}$ & 26 \\
Heaven & $79^{* * *}$ & 36 \\
Sin & $88^{* * *}$ & 53 \\
Reincarnation & $33^{* * *}$ & 22 \\
Amulet, etc. & $41^{* * *}$ & 20 \\
\hline
\end{tabular}

Data source for Hungarian population: EVS 2008

*** Significance level: 0.001

A similarly higher religious attitude can be observed in their opinion on the necessity of religious services, rituals, at different life-turning events, especially at marriage and death (Table 4).

Table 4. The proportion of NoCRoSC students and Hungarians who consider religious services necessary at different events.

\begin{tabular}{lll}
\hline $\begin{array}{l}\text { Religious rituals are important at ... } \\
\text { Event } \\
\text { NoCRoSC (\%) }\end{array}$ & $\begin{array}{l}\text { Hungarians } \\
(\%)\end{array}$ \\
Birth & 77 & 74 \\
Marriage & $93 * * *$ & 72 \\
Death & $89 * *$ & 80 \\
\hline
\end{tabular}

Data source for Hungarian population: EVS 2008

** Significance level: 0.01

$* * *$ Significance level: 0.001

While the students of the special Christian Roma colleges can be considered religious, who require religious rituals at the important events in their life, this religiousness is less witnessed by their participation in religious services. Nevertheless their data still indicates a significantly higher participation rate than that of their Hungarian counterparts among those who visit churches more regularly, i.e. at least monthly (Table 5). Consequently, the proportion of students who never go to a church is much lower. All of these might be explained by the fact that we are talking about students who received boarding in colleges run by the traditional Christian churches of Hungary. 
Table 5. The proportion of NoCRoSC students and Hungarians participating in the events of organised religion

\begin{tabular}{lll}
\hline $\begin{array}{l}\text { Participation rate } \\
\text { frequency }\end{array}$ & $\begin{array}{l}\text { NoCRoSC } \\
(\%)\end{array}$ & $\begin{array}{l}\text { Hungarians } \\
(\%)\end{array}$ \\
Weekly & $30 * * *$ & 9 \\
Monthly & $22^{* * * *}$ & 7 \\
At certain feasts & 22 & 21 \\
Yearly & 5 & 5 \\
Rarely & 14 & 14 \\
Never & $7 * * *$ & 44 \\
\hline
\end{tabular}

Data source for Hungarian population: EVS 2008

*** Significance level: 0.001

Similarly significant differences can be observed between the students' and the Hungarians' views on the areas where the churches might be able to give competent answers and solutions (Table 6). While the differences - with the exception on spirituality - are significant even at the level of 0.001 , it is nevertheless noteworthy that these students consider the churches capable of providing feasible answers both to the social problems and the difficulties of family life. Possible explanations for this high confidence include again the fact that these students are religious and living in church-run colleges where they can learn about the teachings of the Christian churches both on social issues and family life in the spiritual modules of NoCRoSC. For the churches this high level of trust must mean not only a possibility but also an obligation to live up to these expectations.

Table 6. The proportion of NoCRoSC students and Hungarians who think that the churches can give appropriate answers to different problems

\begin{tabular}{lll}
\hline problems & $\begin{array}{l}\text { NoCRoSC } \\
\mathbf{( \% )}\end{array}$ & $\begin{array}{l}\text { Hungarians } \\
\mathbf{( \% )}\end{array}$ \\
Moral & $59 * * *$ & 41 \\
Family & $63 * * *$ & 34 \\
Spiritual & $78^{* *}$ & 61 \\
Social & $53 * * *$ & 19 \\
\hline
\end{tabular}

Data source for Hungarian population: EVS 2008

** Significance level: 0.01

*** Significance level: 0.001

Views on What Children Should be Taught at Home

The EVS survey did not contain questions on education per se, but it asked the respondents to mention five especially important features or qualities what children can and should be taught at home. The results are presented in Table 7 . With the exception of manners, all the other qualities are considered more important and 
possible to teach to children at home by the students of NoCRoSC than by Hungarians. Even the rank order of importance is by and large the same: both groups consider respect, responsibility, sedulity, self-determination, and manners as the most important qualities (although not exactly in the same order). Similarly, the features considered by Hungarians as well as the Roma/Gypsy students to be the least possible to teach at home are fantasy, and somewhat surprisingly, thriftiness and religious faith. This last observation should be especially worth to be considered by the churches and the ecclesiastic leaders of the colleges.

Table 7. The different mean values related to features or qualities what children can and should be taught at home by NoCRoSC students and Hungarians (the lower the value, the more respondents mentioned it).

\begin{tabular}{lll}
\hline Features or qualities & NoCRoSC & Hungarians \\
Manners & 1.22 & 1.17 \\
Self-determination & 1.18 & 1.25 \\
Sedulity & 1.14 & 1.22 \\
Responsibility & 1.10 & 1.24 \\
Fantasy & 1.49 & 1.85 \\
Respect, tolerance & 1.10 & 1.28 \\
Thriftiness & 1.39 & 1.50 \\
Determination, tenacity & 1.24 & 1.71 \\
Religious faith & 1.45 & 1.78 \\
Selflessness & 1.32 & 1.65 \\
Obedience & 1.34 & 1.58 \\
\hline
\end{tabular}

Data source for Hungarian population: EVS 2008

\section{Trust in Social Institutions}

Another block of questions containing a piece of relevance to education was the respondents' trust in different social institutions. Among the eighteen institutions the educational system was also listed. Table 8 presents the Hungarians' and NoCRoSC students' average trust in them with their rank order. 
Table 8. The different mean values of the trust NoCRoSC students and Hungarians have in social institutions (the lower the value, the higher the trust in the institutions).

\begin{tabular}{l|llll}
\hline \multirow{2}{*}{ Institutions } & NoCRoSC & \multicolumn{3}{l}{ Hungarians } \\
\cline { 2 - 5 } & Mean & Rank & Mean & Rank \\
values & Order & values & Order \\
Church & 2,27 & 1. & 2.67 & 7. \\
Armed forces & 3.01 & 11. & 2.71 & $8-9$. \\
Educational system & 2.67 & 6. & 2.49 & 1. \\
Press & 3.28 & 17. & 3.03 & 14. \\
Unions & 3.03 & 13. & 3.04 & 15. \\
Police & 2.89 & 9. & 2.53 & $2-3$. \\
Parliament & 3.13 & 15. & 3.10 & 16. \\
Public administration & 3.07 & 14. & 2.71 & $8-9$. \\
Social security system & 2.88 & 8. & 2.76 & 11. \\
European Union & 2.54 & 4. & 2.54 & 4. \\
NATO & 2.48 & 3. & 2.59 & 6. \\
United Nations & 2.45 & 2. & 2.55 & 5. \\
Health care system & 2.82 & 7. & 2.81 & 12. \\
Justice system & 2.93 & 10. & 2.72 & 10. \\
Large businesses & 3.02 & 12. & 2.89 & 13. \\
Environmental organisations & 2.56 & 5. & 2.53 & $2-3$. \\
Political parties & 3.44 & 18. & 3.32 & 18. \\
\hline Government & 3.22 & 16. & 3.22 & 17. \\
\hline
\end{tabular}

Data source for Hungarian population: EVS 2008

Regarding the two most important institutions from our analytical point of view, it is interesting to note that while the church is the most trustable institution for the Roma/Gypsy students in NoCRoSC, the educational system is the most trusted among Hungarians. It is also noteworthy, that for the two groups church and the educational system are 'exchangeable' in so far if either of them is not at the first place, it is about at the one third of the list $\left(6^{\text {th }}-7^{\text {th }}\right.$ places $)$. Might it be that the students having a current first hand experience of (higher) education are more critical towards it?

It is also worth mentioning that whereas the police force is the second-third most trustable institution for the Hungarians - along with environmental organisations - , it is only ranked $9^{\text {th }}$ among the students. The nationwide impression that the police are prejudiced against the Roma/Gypsy population might be the explanation of this phenomenon.

Although not in the same rank order, but for both groups, the political organisations - the parliament, political parties, the government, as well as the unions and the press - seem to be the most untrustworthy and least dependable.

\section{Attitude towards work}

The socially sensitive question of the Gypsies/Romas' attitude can and must be addressed here. There are contradicting views on whether the Roma/Gypsy people like to work. On the one hand, according to the Hungarians, a 'stereotypical Gypsy' 
avoids work as much as possible. On the other hand, it is generally accepted that if an especially hard, labour-intensive job is to be done, Gypsies should be called. ${ }^{13}$

From the EVS survey and the research conducted among the students of NoCRoSC we can not solve this ambiguous situation, but we can assume that the attitude of Roma/Gypsy people towards work is different (Table 9.)

Table 9. The different mean values of the agreement NoCRoSC students and Hungarians expressed on statements regarding work (the lower the mean value, the higher the level of agreement).

\begin{tabular}{lll}
\hline & \multicolumn{2}{l}{ Mean values of agreement } \\
& NoCRoSC & \multicolumn{1}{l}{ Hungarians } \\
Work is always at the first place, even if it jeopardises & $3.15^{* * *}$ & 2.30 \\
free-time & & \\
It is humiliating to get money if one does not work for it. & $3.18^{* * *}$ & 2.42 \\
Work is necessary for dénouement, self-realisation & $2.22^{* * *}$ & 1.77 \\
\hline
\end{tabular}

Data source for Hungarian population: EVS 2008 *** Significance level: 0.001

As we can see in Table 9, for the Roma/Gypsy students, compared to the Hungarians, work is not always at the first place, especially not, if it means less freetime. However, we must recall, that just like the Hungarians, Roma/Gypsy students considered work as the second most important item in their life after their families, and it was considered more important by them then by their Hungarian counterparts..$^{14}$

Compared to Hungarians, these students find it humiliating to a lesser extent if one receives money without working for it. Similarly, they do not reflect on work as necessary for self-realisation or dénouement. All in all, while they consider work as an important component of their life, their attitude towards it significantly differs from that of their Hungarian peers. It does not take such a central and dominant position in their life as it does in the Hungarians' case.

\section{Instead of A Summary - Some Concluding Remarks}

The simple intention of this paper was to inform the public about the value-system of the students of NoCRoSC by presenting some preliminary results on religion, education and other related topics. It was done in the hope of highlighting some possible trends to which attention should be paid in the future. One of these possible trends is the higher importance they placed on work; another - in comparison with the Hungarians - is the lower significance they attributed to family. It will also remain to see whether their higher religiosity prevails.

\footnotetext{
${ }^{13}$ The author's personal experience was in the mid seventies in a technical school that when the question of an extremely hard, not mechanisable work was discussed, the teacher recommended to call for the 'Brazilian machinery' meaning the Roma/Gypsy people.

${ }^{14}$ C.f. the results presented in Table 2.
} 
For the churches it is encouraging that these young people trust them very much, not only as an institution, but also as a guiding source in social, moral, and spiritual matters. It must also be tested from time to time whether and how their attitude towards work develops.

There is still one important item which should be checked in the future: happiness. If we compare the Hungarians' average with that of the Roma/Gypsy students on the question of how happy they are, and especially, if we control age, we find that Roma/Gypsy students are significantly happier than the Hungarians are. ${ }^{15}$ This condition of being happier was confirmed by some of the students in NoCRoSC. When we gave feedback to the students in the college run by the Jesuit order in Budapest, one of the medical students reflected on the data and his own experience, and claimed in a telling way: "Yes, as a Gypsy, I was happier!" We might consider the situation hopeful that if their level of happiness is still significantly higher than that of the Hungarians, this happiness prevails.

In an effort of changing the Afro-Americans self-perception and attaining a positive social identity, the leaders of the North-American civil rights movement introduced a slogan, a catchphrase: Black is beautiful! In a similar way, we might suggest not unsubstantiatedly ${ }^{16}$ that the Gypsy is happier!

\section{References}

Ashford, S. A. \& Halman, L. (1994). Changing attitudes in the european community. In C. Rootes \& H. Davis (Eds.), Social change and political transformation (pp. 72-85). London: UCL Press.

Forray, R. K. (2004a). Életutak, iskolai pályák. Interjúk cigány, roma fiatalokkal [Life Stories, School Carriers. Interviews with Gypsy, Roma Students]. Pécs: PTE BTK Neveléstudományi Intézet Romológia és Nevelésszociológia Tanszék.

Forray, R. K. (2004b). "Ebbe a dolgozatba beleírtam a lelkemet" Cigány gyermekek a közösségeikröl ["My soul is written in this paper". Gypsy childrean about their communities]. Manuscript.

Forray, R. K. \& Marton, M. (2012) Egyházi szakkollégiumok [Special Church-Run Colleges]. Iskolakultíra, 22(7-8), 35-44.

Halman, L., Sieben, I. \& van Zundert, M. (Eds.) (2011). Atlas of European Values. Trends and Traditions at the turn of the Century. Leiden: Brill.

\footnotetext{
${ }^{15}$ The difference between the Roma/Gypsy students and their Hungarian counterparts in the same age group (under 26) is significant on the 0.001 level.

${ }^{16}$ Apart from the data presented in this study, in a manuscript, Forray (2004b) presents similar findings. Analyzing the composition works of sixty-five elementary school children on Roma/Gypsy communities, she collected the features and qualities attributed to them. Among the positive emotional features - such as nice, joking, friendly, family- and childloving - can "joyous/joyful/happy" also be found. According to Forray's information, the manuscript will be soon published.
} 
Huszti, É., Dávid, B. \& Vajda, K. (2013) Strong Tie, Weak Tie and In-Betweens: A Continuous Measure of Tie Strength Based on Contact Diary Datasets. Procedia Social and Behavioral Sciences, 79, 38-61.

Kállai, E. \& Törzsök E. (Eds.) (2006). Átszervezések kora: cigánynak lenni Magyarországon : jelentés 2002-2006 [A Period of Reorganizations: Being a Gypsy in Hungary - Report 2002 - 2006]. Budapest: Európai Összehasonlító Kisebbségkutatások Közalapítvány.

Kende, A. (2005). Értelmiségiként leszek roma, és romaként leszek értelmiségi. Vizsgálat roma egyetemisták életútjáról [As an intellectual, I will becoma a Roma, and as a Roma, I will become an Intellectual]. In M. Neményi \& J. Szalai (Eds.), Kisebbségek kisebbsége. A magyarországi cigányok emberi és politikai jogai (pp. 376408). Budapest: Új Mandátum.

Kemény, I., Janky, B. \& Lengyel, G. (2004). A magyarországi cigányság 1971-2003 [Romani/Gypsy People of Hungary 1971-2003]. Budapest: Gondolat.

Kertesi, G. (2005). A társadalom peremén [On The Edge of the Society]. Budapest: Osiris.

Kyuchukov, H. (2011). Roma girls: between traditional values and educational aspirations. Intercultural Education, 22(1), 97-104

Lukács, Á. (2011). Roma értelmiségiek identitása [The Identity of Roma Intelligentsia]. Valóság, 54(10), 79-95.

Morel, Gy. (1989). Szociológia [Sociology]. Budapest: Semmelweis Egyetem Mentálhigiéné Intézet - Dialógus (Párbeszéd) Alapítvány.

Pusztai, G. (2004). Kapcsolatban a jövővel. [In Contact with the Future]. Valóság, 47(5), 69-84.

Rosta, G. \& Tomka, M. (Eds.) (2010). Mit értékelnek a magyarok? Az Európai Értékrend Vizsgálat 2008. évi magyar eredményei [What do the Hungarians value? The results of the European Value Surveys conducted in 2008]. Budapest: Agóra IX. OCIPE Magyarország - Faludi Ferenc Akadémia.

Szabóné, K. J. (2005). A magyarországi cigány értelmiség helyzete és mentális állapota [The Situation and the Mental State of the Hungarian Roma Intelligentsia]. Pécs: PTE BTK Neveléstudományi Intézet Romológia és Nevelésszociológia Tanszék.

Tóth, K. D. (2004). Magyarországi és angliai kiemelkedett cigányok identitástipusainak összehasonlitó elemzése [Comparative Study on the Identity Types of Successful Gypsies/Travelers in Hungary and in England]. Budapest: Corvinus Egyetem.

Török, P., Martos, T. \& Horváth-Szabó, K. (2010). Család, házasság és párkapcsolatok az értékek és elégedettség fényében [Family, Marriage and Partnership in Light of Values and Satisfaction] In G. Rosta \& M. Tomka (Eds.), Mit értékelnek a magyarok? Az Európai Értékrend Vizsgálat 2008. évi magyar eredményei. (pp. 53-80). Budapest: Agóra IX. OCIPE Magyarország - Faludi Ferenc Akadémia. 